\title{
FIELD OBSERVATIONS IN UPPER PALAEOZOIC AND MESOZOIC SEDIMENTS OF SCORESBY LAND AND JAMESON LAND
}

T. Birkelund and K. Perch-Nielsen

Introduction

The main object - and the main problem - in the 1968 summer mapping in southern Scoresby Land and northern Jameson Land was to correlate three existing but not yet published geological maps on the new topographic map (see fig. 1). Thanks to the generosity of the geologists concerned (M.Aellen, J.H.Callomon, R. Trümpy and K. Grasmück) we had these maps at our disposal, as well as descriptions to the latter two maps.

The mapping was carried out by T.Birkelund, K. Perch-Nielsen, F.Surlyk, L. Malmros, E.Håkansson, and W. Kegel-Christensen.

\section{Palaeozoic}

No detailed studies were made on the Palaeozoic sediments which appear at the western and eastern border of the basin. A new outcrop, probably of Upper Devonian age, was found in the river falling into Nathorst Fjord. The deposits consist of dark sandstones and dip strongly westwards.

Upper Permian sediments could be studied at the head of Nathorst Fjord (the "Depot Island Formation", see Säve-Söderbergh, 1937) and in the area uplifted by the Tertiary Werner Bjerge intrusion. North of Nordenskiöld Bjerg they consist of tectonically disturbed dolomites, sandstones, and conglomerates. No fossils were found at this locality, but in the valley at the head of Nathorst Fjord in some ice-moulded hummocks we found productids, spiriferids, echinids, bryozoans and a single fish 
(determined by S.Bendix-Almgreen as Platysomus sp.) . Loose Permian blocks with spiriferids were found in the lower part of Pingel Dal. Southeast of Werner Bjerge productids and bryozoans are present in Permian deposits.

The central part of the basin is covered by Triassic and Jurassic sediments and no Palaeozoic deposits are exposed.

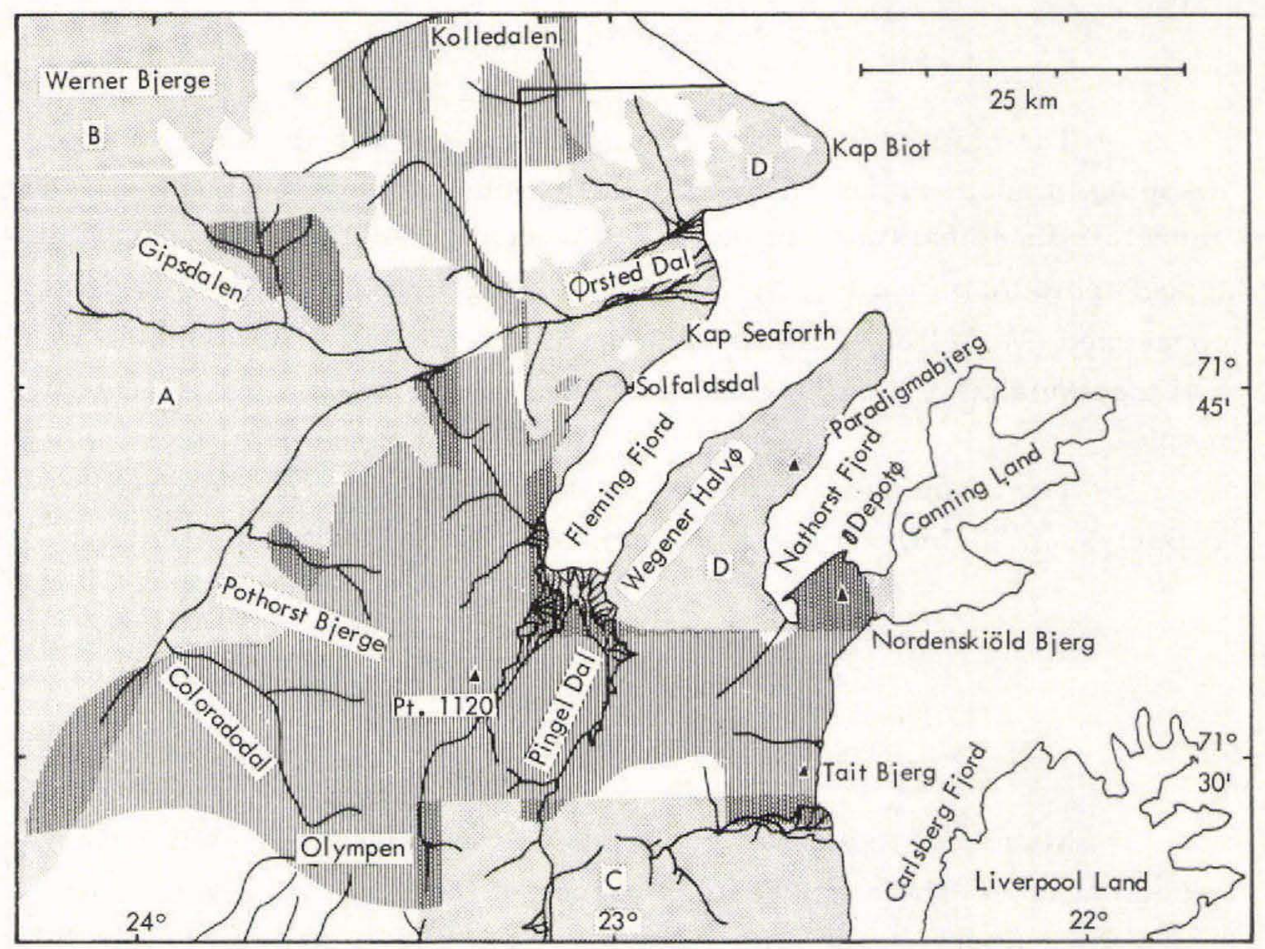

Fig. 1. Map of Scoresby Land (the area north of $\emptyset$ rsted Dal) and northern Jameson Land, showing localities mentioned in the text, areas studied during

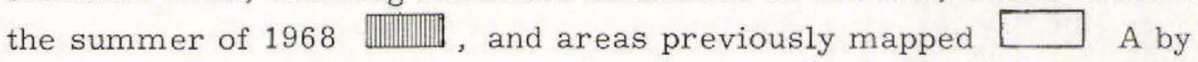
M. Aellen, B by P.Bearth and E. Wenk, C by J.H. Callomon, and D by R. Trümpy and K. Grasmück. 
Triassic and Jurasic

For the mapping of the Triassic and Jurassic deposits (see fig.2) the lithostratigraphical classification used by Trümpy (1961) and Callomon (1961) (see table 1) was utilised in the field. These authors combined the observations and classifications of previous investigators: Hartz (1896), Koch (1929a, 1929b), Rosenkranz (1929, 1934), Noe-Nygaard (1934), and Stauber (1942). Trümpy (1961) also established a further sub-division of the Triassic. Our definite decision as to the boundaries of the members and formations will only be taken after a visit to all type localities, as the application of some of these boundaries presented certain difficulties.

\section{Wordie Creek Formation}

A nearly complete section through the Wordie Creek Formation was found in Gipsdalen. In Pingel Dal and at the south-western end of Nathorst Fjord, as well as north of Nordenskiöld Bjerg, only scattered outcrops were visited.

The Wordie Creek Formation consists mainly of greenish-grey and dark brown silty shales and sandstones. The fossil assemblage encountered is very poor, both in content and preservation, and includes ammonites (Ophiceras, Discophiceras), pelecypods (Anodontophora, Claraia, Myalina), brachiopods (Discinidae), and sparse remains of plants. Both Grasmück and Trümpy (in press) in the eastern part of the basin at Wegener Halv $\phi$, and M. Aellen (in Trümpy, 1961) in the western part, found a richer fauna. M.Aellen (in Trumpy, 1961) mentions the Rødstaken beds, a new member between the Wordie Creek Formation and the overlying Paradigma Member. We met this not yet defined member in Gipsdalen, where it consists of a coarse, often yellowish basal conglomerate of variable thickness, and grey-reddish sandstones with flute casts, parting lineation, ripple marks, cross-bedding and slump structures. Sporadically Anodontophora and Claraia could be observed. Similar sandstones were seen in the same stratigraphic position in the Nathorst Fjord area and are recorded by Trümpy (1961) on Wegener Halv $\phi$. The boundary to the overlying beds seems rather arbitrary, both on Wegener Halv $\phi$ (Grasmück and Trumpy, in press) and in Gipsdalen, where the sandstones of the Rфdstaken Member grade into arkoses of the Paradigma Member. 
Legend:

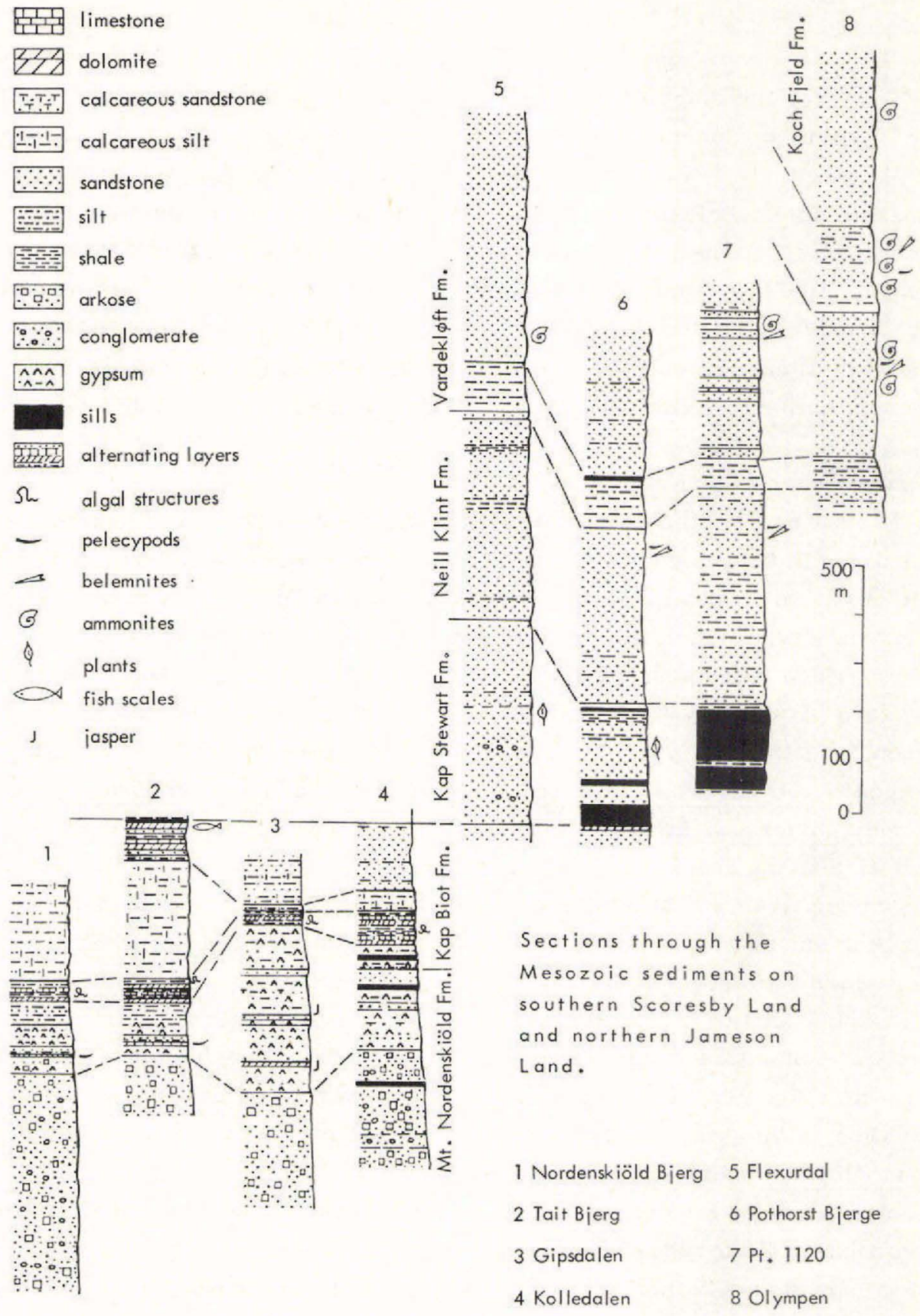


Mt. Nordenskiöld Formation

The lowest member of the Mt. Nordenskiöld Formation, the Paradigma Member, could be studied in the eastern and western border regions of the basin. On Nordenskiold Bjerg - the type locality - the contact between the Wordie Creek Formation and the Mt. Nordenskiold Formation is not exposed.

In both areas studied the Paradigma Member consists of important sequences of arkoses interfingering with conglomerates and sandstones. Conglomeratic layers are thickest and most frequent in the middle part of the member. They consist of a loose to hard arkosic to sandy groundmass and boulders up to $25 \mathrm{~cm}$ in diameter. The pebbles are normally well rounded and consist mainly of porphyry, granite, quartzite, gneiss and limestone. The arkoses and sandstones are often cross-bedded, especially towards the top of the member. Here pea-sized gypsum-filled holes often occur in the incompletely cemented arkoses. The arkoses are pink, salmon-pink to red and lilac-red in the eastern area and dominantly red-brown in Gipsdalen, probably due to different directions of derivation of the componerits : from the west in the western part and from the east in the eastern part. The reddish colours are often due to the red or pink feldspar components.

The boundary to the overlying member, the Solfaldsdal Member, was also often difficult to fix in the region visited. Sandstones and arkoses gradually become gypsiferous and finally pure gypsum layers occur interbedded with sandstones and shales.

In the area mapped by Trümpy and Grasmück the Solfaldsdal Member, when typically developed, consists of the following lithological units (from below) : 1) soft, gypsum-bearing shales, 2) a calcareous, fossil-bearing zone ("Myalina limestone"), 3) sandstones and siltstones.

West of the area mapped by Trumpy and Grasmück the member shows certain lithological differences. The lower unit consists here of alternating sandstones, gypsiferous sandstones and pure gypsum layers, while shales are subordinate or lacking. According to Grasmück and Trümpy lithological changes occur also south of Fleming Fjord, the gypsum-bearing shales being replaced by coarse, gypsum-bearing arkoses on Profilbjerg. 
Table 1

Mesozoic stratigraphical units in southern Scoresby Land and northern Jameson Land

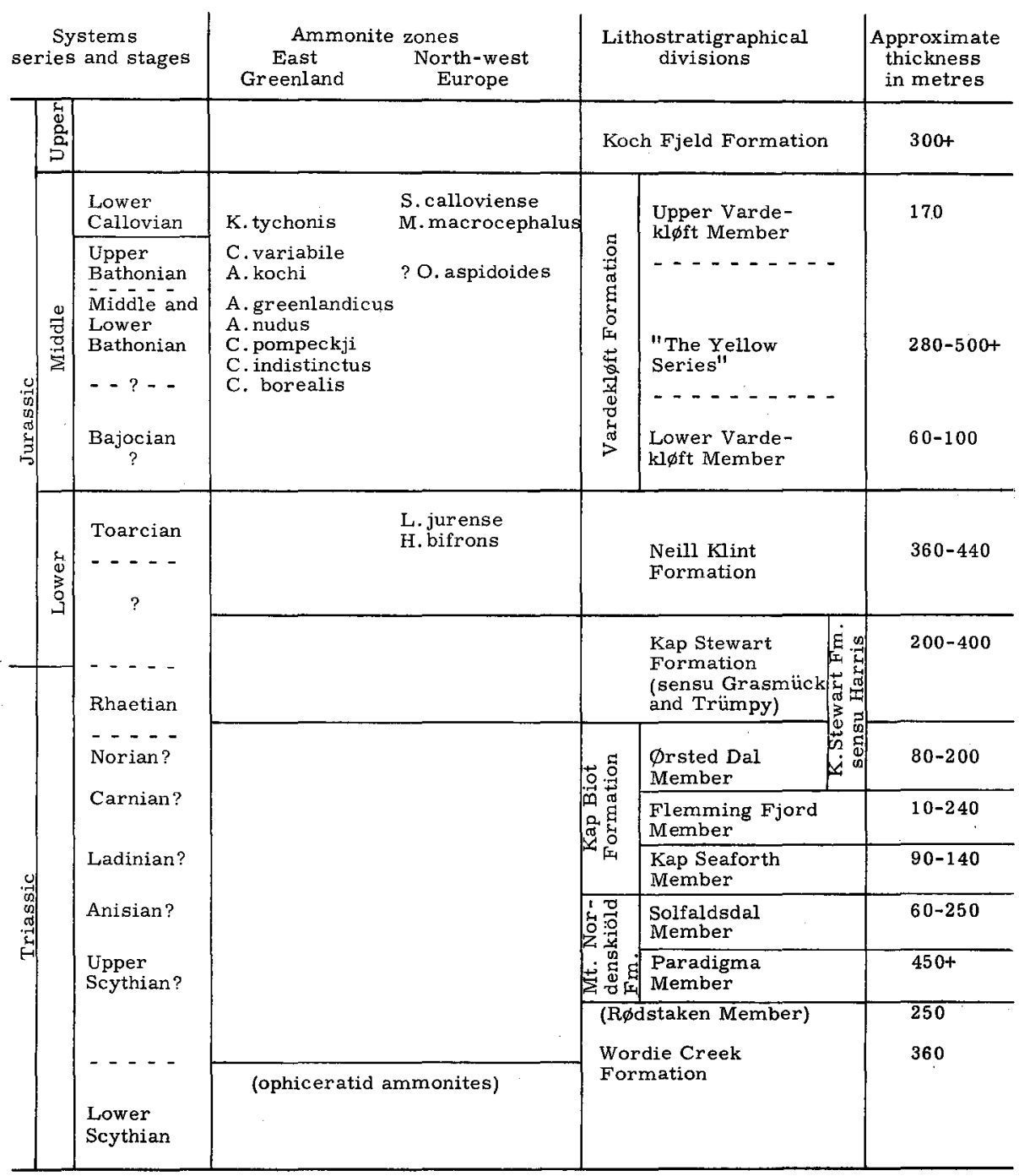


The "Myalina limestone" of the Fleming Fjord area can possibly be compared with thin layers of fossiliferous marls and bituminous limestones in the area west of Carlsberg Fjord and to dolomite (occurring only as loose boulders in the scree) in Gipsdalen.

Both near and at Nordenskiöld Bjerg, as well as in the western part of the region, jasper has been found in grey sandstones below and above the "Myalina limestone". Stauber (1942) also mentions the occurrence of jasper ("Karneol") at Nordenskiöld Bjerg.

In the northern areas of the region the uppermost part of the Solfaldsdal Member consists of red and grey, often calcareous, sandstones with thin gypsum intercalations, the gypsum being more prominent in the lower part than in the upper part of the member.

\section{Kap Biot Formation}

Trümpy (1961) referred the gypsiferous beds above the uppermost sandy beds of the Solfaldsdal Member to the Kap Biot Formation and included them in the Kap Seaforth Member. The member thus consists of a lower, gypsiferous sequence and an upper, dolomitic - calcareous sequence.

In the Kap Biot area the gypsiferous part of the Kap Seaforth Member comprises cyclic sequences of variegated gypsum-bearing sandstones and gypsum-bearing shales totalling $80-100 \mathrm{~m}$ in thickness. Both Grasmück and Trümpy (in press) and Noe-Nygaard (1934) noted a thinning of the gypsiferous sequence to the south and to the east.

In the south-eastern part of the region investigated, the gypsiferous unit is thinner but its development seems to be similar to that in the Kap Biot area; it comprises brown-red gypsiferous silts forming slopes which are normally covered by scree from the upper part of the Kap Seaforth Member and the Fleming Fjord Member. However, in the northern and western part of the region investigated a very characteristic, up to $70 \mathrm{~m}$ thick sequence of alternating layers of gypsum, gypsiferous light grey sandstones and dark shales or siltstones make up the base of the Kap Seaforth Member. These beds occur as a light coloured band between the reddish and brownish sediments below and above and act as a natural marker unit in the field. 
The upper dolomitic part of the Kap Seaforth Member and the overlying Fleming Fjord Member form steep cliffs around Carlsberg Fjord and Fleming Fjord, and also in the areas around Kolledalen, $\emptyset_{\text {rsted Dal }}$ and Pingel Dal.

The upper part of the Kap Seaforth Member is very uniform throughout the whole region, consisting of dolomitic and calcareous layers with intercalations of thin silt and sandstone horizons. The proportion of sandstone increases towards the top of the member.

The massive dolomitic limestone beds contain pyrite, bitumen and terrigenous detrital material. Certain horizons show extremely well preserved stromatolithic structures, and their similarity to fold structures led Stauber (1942) to assume mass-sliding on these horizons. The algal structures are often disturbed and certain horizons are built up of detrital algal material mixed with terrigenous material and cemented by calcite. The detritus comprises grains of quartz, feldspar, some heavy minerals and a little muscovite and is sometimes encrusted by dolomite. A detailed study on the genesis of this unit is planned. Pelecypods occur sporadically in certain horizons.

Ripple marks, mud-cracks, borings and questionable remnants of algal growths often occur on the bedding planes of the sandy horizons. The boundary with the overlying red-brown siltstones and mudstones of the Fleming Fjord Member is transitional in most localities. Reddish siltstones appear as intercalations in the organic-chemical sediments, become progressively more dominant upwards and finally calcareous layers and sandstones are present only as thin intercalations.

In the well bedded, often calcareous, red siltstones and mudstones, mud-cracks and trace fossils (interpreted as "Schlammwülste" by Stauber, 1942) are common on the bedding planes. Ripple marks, sometimes aligned at angles of $90^{\circ}$ to each other in two successive layers, are also common. Fine scale cross-bedding and flaser structures, mud boulders, and load casts complete the diverse picture of the sedimentary structures, most of which have been previously described by Stauber (1942). No fossils were found by us in this member. In thickness, the Fleming Fjord Member varies considerably; the greatest thickness occurs in the south-eastern areas and it is thinnest or absent in Gipsdalen. 
The uppermost part of the Fleming Fjord Member passes gradually into the overlying $\emptyset$ rsted Dal Member. This member was established by Trümpy (1961) and referred to the Kap Biot Formation. Grasmück and Trumpy suppose that it is equivalent to the lower, sterile part of the Kap Stewart Formation as described from southern Jameson Land by Rosenkrantz (1929) and Harris (1937).

In both the area mapped by Trumpy and Grasmück and in the area mapped by us, the $\phi$ rsted Dal Member shows considerable variation in thickness (from 80 to $200 \mathrm{~m}$ ) and lithology. In the region visited its lower part consists often of massive calcareous sandstone beds with intercalations of reddish siltstones. The sandstone beds are often cross-bedded and ripple marks commonly occur in the lowermost part. In the middle part of the member the sandstones are dominant and the siltstones subordinate, while calcareous and dolomitic horizons may be prominent in the upper part. The upper boundary is marked by a bone-bed in the area mapped by Trümpy and Grasmück. At the same level however, we found on Tait Bjerg only a calcareous silt with fish scales and fish teeth. In $\emptyset_{\text {rsted Dal indications of }}$ considerable erosion occur in the upper part of the member, where coarse sandstone horizons contain large blocks of $\emptyset_{\text {rsted }}$ Dal dolomite.

\section{Kap Stewart Formation}

The Kap Stewart Formation (sensu Grasmück and Trümpy) is 200-400 $\mathrm{m}$ thick in the region visited and thus considerably thicker than in southern Jameson Land where it never exceeds $100 \mathrm{~m}$. It consists of light coloured sandstones, often cross-bedded and poorly sorted, and dark coloured often blue-black shales. No red weathering occurs. Only few and poorly preserved plant fossils were found, none of them comparable to the famous plant fossils described by Harris (1931-32, 1935, 1937, 1946) from southern Jameson Land.

\section{Neill Klint Formation}

The Neill Klint Formation varies in thickness from about 350 to about $450 \mathrm{~m}$ in the region visited.

The boundary between the Kap Stewart Formation and the overlying Neill Klint Formation in southern Jameson Land is marked by a marine transgression giving rise to coarse, often conglomeratic arkoses 
containing a diverse Pliensbachian fauna. In the northern region the boundary is more obscure and it was placed at the level where coarse, poorly sorted Kap Stewart sandstones and shales were replaced by brownish, rather well sorted, micaceous sandstones. Flaser structures and mud-cake conglomerates are common and the many trace fossils and borings indicate coastal environments. Higher in the sections large-scale cross-bedding occurs and coarse sandstone horizons are more common than in the lower part. The uppermost part consists of alternating sandy and silty horizons. The sandstones are highly variable in grain size, degree of bedding and weathering colour, brown and reddish weathering colours being predominant. While the lower part contains only few and insignificant fossils, the upper part contains abundant Toarcian fossils in certain places. These assemblages are dominated by pelecypods but belemnites and ammonites also occur (Dactylioceras, Pseudolioceras). Poorly preserved, scattered plant fossils were seen throughout the formation.

\section{Vardekl $\phi$ ft Formation}

The Vardekl $\phi \mathrm{ft}$ Formation begins with black silty shales containing dark concretions with a diameter of $10-15 \mathrm{~cm}$. The boundary to the underlying sandstone of the Neill Klint Formation is well defined, but often covered by scree. The Lower Vardekl $\phi \mathrm{ft}$ shales vary in thickness from 60 to $100 \mathrm{~m}$ in the region mapped. They gradually become more sandy in the upper part and the concretions disappear. No fossils are found in this part of the sequence.

The sandy shales are overlain by a sequence of sandstone and silt called the "Yellow Series". The thickness of this unit is highly variable within the region visited $(280->500 \mathrm{~m})$ with a general increase in thickness northwards. "The Yellow Series" consists of light grey, often massive sandstone beds with intercalated silty horizons. The sandstones usually weather yellowish, are often cross-bedded and are rather poorly sorted. Some horizons contain scattered, well rounded quartzite pebbles, others rusty sandstone concretions. Many horizons contain abundant trace fossils, the types differing from level to level. Except for these trace fossils and scattered plant remains, fossils are scarce north of Olympen, only sporadic occurrences of belemnites and ammonites being met with. However, south and west of Olympen rich faunas occur in these beds. 
The upper part of the Vardekløft Formation consists of light grey, silty shales with a few brownish-weathering sandstone horizons in which fossils are abundant. It is not known from the area north of Coloradodal.

The fauna of the Vardekl $\phi \mathrm{ft}$ Formation has previously been described by Spath (1932) on the basis of collections from the area south of Carlsberg Fjord. After further collecting, Callomon (1959, 1961) revised the ammonite zones established by Spath and showed the presence of nine ammonite zones. The two upper zones contain ammonites comparable to forms represented in the Lower Callovian Macrocephalites macrocephalus Zone and Sigaloceras calloviense Zone. The seven lower zones contain rich boreal ammonite assemblages, but no ammonites occurring outside the boreal realm had been found. This caused great correlation problems (see Callomon, 1959). However, lucky finds in the Arcticoceras kochi zone of some Oxycerites very similar to $O$.aspidoides from Europe may give a new fixed point for the correlation. They seem to confirm Callomon's preliminary correlation of the Arcticoceras kochi zone and the Cadoceras variabile zone with the Upper Bathonian.

Koch Fjeld Formation

The highest summits south of Coloradodal are built up of a massive sandstone unit referred to the Koch Fjeld Formation. The sandstone is rather well sorted and often cross-bedded. A few poorly preserved belemnites and ammonites were found. One of the ammonites is a keeled, finely ribbed cartioceratid form. A single Amoeboderas found in the type area of this formation on southern Jameson Land is the only ammonite previously known from this formation.

$$
\text { Tertiary }
$$

Tertiary intrusions of different character can be observed in the region investigated. Of the intrusive massive of Werner Bjerge (see Bearth, 1959) we met only boulders in the river system of Gipsdalen, and in moraines. Doleritic dykes and sills occur throughout the region. Dykes are 
particularly numerous in the surroundings of Werner Bjerge. The dykes are from a few centimetres to about 10 metres thick and often vertical. The sills are generally concordant between the bedding planes and their thickness varies considerably over short distances. Sills up to $150 \mathrm{~m}$ thick can be found in the area around and east of Pothorst Bjerge to Pingel Dal, as well as between Kolledalen and $\emptyset$ rsted Dal. In the area around Pothorst Bjerge two major sills can be recognised; the lower one, about 40 to $150 \mathrm{~m}$ thick, mainly consists of fine-grained dolerite, and the upper one, about $30 \mathrm{~m}$ to $90 \mathrm{~m}$ thick, consists of dolerite with up to $8 \mathrm{~cm}$ long feldspars. Baked sedimentary lenses and layers, a few decimetres in thickness, can often be observed in the sills. In the contact zones the sandstones are baked and black shales of the Kap Stewart Formation are silicified and bleached. Most of the thick sills were observed intruded into the Kap Stewart Formation; however, some were also recorded in the Kap Biot Formation, the Neill Klint Formation and the R $\phi$ dstaken Member.

\section{Structure}

On Liverpool Land and on Canning Land the basement of the Palaeozoic and Mesozoic sediments is exposed. On Wegener Halv $\phi$ and on Canning Land strongly faulted and tilted Upper Palaeozoic and Lower Triassic deposits occur (see Noe-Nygaard, 1934: Bütler, 1957: Grasmück and Trümpy, in press). To the west, south-west and north-west we find still higher units, gently dipping to the south-west. Important faults ( $>1000 \mathrm{~m}$ throw) striking more or less north-south mark the western and eastern borders of the northern Jameson Land basin. Many faults with about 5-500 $\mathrm{m}$ throw were found around Werner Bjerge, north of $\emptyset$ rsted Dal and south of Carlsberg Fjord. While most faults strike about northsouth, other directions occur and nearly east-west faults are known. Flexures are known to exist in the north-eastern part of the area (see Grasmück and Trümpy, in press) and have been met in the western Kap Biot area and south of Kolledalen. Small folds are observed in some incompetent shaly layers of the Wordie Creek Formation in Gipsdalen. 
They seem to be connected to faults and flatten out about $100 \mathrm{~m}$ from the faults. The age of the faults and folds is probably Tertiary. The main faults, however, follow late Palaeozoic lineaments.

Quaternary

Well developed Quaternary moraines are very scarce to the north but more widespread in the southern part of the region. The gravels occurring on the plateau mountains have previously been noted by Nordenskiold (1907). They consist of erratic, rather well rounded boulders of gneiss, granite, quartzite and Scolithos sandstone. The gravel may be considered as remnants of ground moraine.

In the southernmost part of the region visited (on Michaels Bjerg, about $30 \mathrm{~km}$ south of Olympen and $400 \mathrm{~m}$ above sea-level) an $8 \mathrm{~m}$ thick section of horizontally bedded unconsolidated sands is exposed, overlain by $0.5 \mathrm{~m}$ of solifluction scree. The few pollen grains present in samples from this locality were examined by S.Funder. The grains are poorly preserved and probably reworked from Upper Cretaceous or Tertiary deposits. Sediments of this age, however, are not yet known from Jameson Land or Scoresby Land. The heavy mineral assemblage of the same samples contains spinel, garnet, rutile, zircon, tourmaline and a little amphibole. No pyroxene has been found as would have been expected if the sands were derived from plant-bearing Tertiary deposits related to basaltic flows such as are known from the area south of Jameson Land. The origin of this sediment is uncertain and needs further investigation.

Post-glacial marine terraces up to $70 \mathrm{~m}$ above sea-level have been met with around Nathorst Fjord and Carlsberg Fjord. The age of the collected pelecypods, Mya truncata, Saxicava arctica and Astarte sp. will be determined by $\mathrm{C}_{14}$-dating. 


\section{References}

Bearth, P. (1959) On the alkali massif of the Werner Bjerge in East Greenland. Meddr Grфnland, Bd. 153, Nr. 4.

Bütler, H. (1957) Beobachtungen an der Hauptbrunchzone der Kuste von Zentral-Ostgrönland. Meddr Grфnland, Bd. 160, Nr. 1.

Callomon, J.H. (1959) The ammonite zones of the Middle Jurassic beds of East Greenland. Geol. Mag., Vol. 96, 505-513.

Callomon, J.H. (1961) The Jurassic system in East Greenland. In Raasch, G.O. (edit.) Geology of the Arctic, Vol. 1, 258-268. Toronto U.P.

Grasmück, K. and Trümpy, R. (in press) Triassic stratigraphy and general geology of the area around Fleming Fjord (East Greenland).

Harris, T.M. (1931-32) The fossil flora of Scoresby Sound East Greenland. Parts 1-3. Meddr Grønland, Bd. 85.

Harris, T.M. (1935 and 1937) The fossil flora of Scoresby Sound East Greenland. Parts 4 and 5. Meddr Grфnland, Bd. 112.

Harris, T.M. (1946) Liassic and Rhaetic plants collected in 1936-38 from East Greenland. Meddr Grфnland, Bd. 114, Nr. 9.

Hartz, N. (1896) Planteforsteninger fra Cap Stewart i $\varnothing$ stgr $\varnothing$ nland, med en historisk Oversigt. Meddr Grønland, Bd. 19.

Koch, L. (1929a) The geology of East Greenland. Meddr Grønland, Bd. 73, Afd. 2, Nr. 1.

Koch, L. (1929b) Stratigraphy of Greenland. Meddr Grфnland, Bd. 73, Afd. 2, Nr. 2 .

Noe-Nygaard, A. (1934) Stratigraphical outlines of the area round Fleming Inlet (East Greenland). Meddr Grфnland, Bd. 103, Nr. 1.

Nordenskiöld, O. (1907) On the geology and physical geography of EastGreenland. Meddr Grфnland, Bd. 28.

Rosenkrantz, A. (1929) Preliminary account of the geology of Scoresby Sound district. Meddr Grфnland, Bd. 73, Afd. 2, Nr. 1, 135-154. 
Rosenkrantz, A. (1934) The Lower Jurassic rocks of East Greenland; Part 1. Meddr Grфnland, Bd. 110, Nr. 1.

Säve-Söderbergh, G. (1937) On the Palaeozoic stratigraphy of Canning Land, Wegener peninsula, and Depot Island (East Greenland). Meddr Grønland, Bd. 96, Nr. 5.

Spath, L.F. (1932) The invertebrate faunas of the Bathonian-Callovian deposits of Jameson Land (East Greenland). Meddr Grфnland, Bd. 87, $\mathrm{Nr} .7$.

Stauber, H. (1942) Die Triasablagerungen von Ostgrönland. Meddr Grфnland, Bd. 132, Nr. 1.

Trümpy, R. (1961) Triassic of East Greenland. In Raasch, G.O. (edit.) Geology of the Arctic, Vol. 1, 248-254. 